Article

\title{
Does Information Asymmetry Affect Dividend Policy? Analysis Using Market Microstructure Variables
}

\author{
Seonhyeon $\mathrm{Kim}^{1}{ }^{1}$, Jin-young Jung ${ }^{2, *(\mathbb{D})}$ and Sung-woo Cho ${ }^{3, *(\mathbb{D}}$ \\ 1 Business School, Korea University, Seoul 02841, Korea; ejejfl3@korea.ac.kr \\ 2 College of Business Administration, Inha University, Incheon 22212, Korea \\ 3 College of Computing, Sungkyunkwan University, Suwon 16419, Korea \\ * Correspondence: jyjung@inha.ac.kr (J.-y.J.); sungwooc@skku.edu (S.-w.C.)
}

check for

updates

Citation: Kim, S.; Jung, J.-y.; Cho, S.-w. Does Information Asymmetry Affect Dividend Policy? Analysis Using Market Microstructure Variables. Sustainability 2021, 13, 3627. https://doi.org/10.3390/su13073627

Academic Editor: Zong Woo Geem

Received: 26 February 2021

Accepted: 20 March 2021

Published: 24 March 2021

Publisher's Note: MDPI stays neutral with regard to jurisdictional claims in published maps and institutional affiliations.

Copyright: (c) 2021 by the authors. Licensee MDPI, Basel, Switzerland. This article is an open access article distributed under the terms and conditions of the Creative Commons Attribution (CC BY) license (https:/ / creativecommons.org/licenses/by/ $4.0 /)$.

\begin{abstract}
This study analyzes the relationship between information asymmetry and dividend policy in an emerging market, Korea. We adopt several proxies for information asymmetry, such as the Glosten-Harris and Hasbrouk-Foster-Viswanathan models, drawn from market microstructure literature. This study finds a negative relationship between information asymmetry and dividend yields, which appears to be particularly strong when firms have difficulty raising external capital because they have high systematic risk, financial constraints, or low stock liquidity. This result, based on an analysis using market microstructure variables that provide direct measures of information asymmetry, suggests that the pecking order theory holds for the Korean stock market and that information asymmetry is a strong determinant of dividend policy decisions in an emerging market.
\end{abstract}

Keywords: dividend yield; information asymmetry; pecking order theory; cost of capital; internal financing

\section{Introduction}

This study examines how informational asymmetries affect firms' dividend policies by investigating the relationship between a firm's dividend policy and the direct measures of information asymmetry drawn from the market microstructure model. Dividend policies are one of the most usual ways to return corporate performance to shareholders. However, since a company's dividend payouts may reduce internal capital and, thus, require external capital financing, a company should set up an appropriate dividend policy that maintains the firm's sustainable growth. There are two competing views on how information asymmetry impacts dividend decisions. The signaling view of dividend policy [1] argues that corporate dividend payouts can provide information to outside investors [2,3]. Firms convey positive signals to external investors through dividend payouts, and investors who experience information asymmetry reassess the available corporate cash flow information. Investors also reevaluate the firm's risk through its dividend level [4-6]. Therefore, companies with severe information asymmetry have a motivation to adopt a higher level of dividend payouts to reduce the information asymmetry experienced by investors. However, the pecking order theory [7] suggests that it is harder for firms with severe information asymmetry to raise external capital by issuing new stocks. Firms facing restrictions on external financing have an incentive to hold internal capital, and such firms are likely to be reluctant to pay a dividend. Some of the evidence suggests that there is a negative relationship between information asymmetry and dividend payouts [8,9].

These two opposing views on information asymmetry and dividend policy have been much-discussed. Many studies have developed tests to examine dividend signaling models. However, our study may be the first to specifically examine the pecking order theory in the context of the relationship between firms' information asymmetry levels and their dividend policies. This study focuses on measuring information asymmetry and external financing difficulty in two ways. First, this study complements the method of estimating information asymmetry based on market microstructure literature. The study examines the 
relationship between information asymmetry and dividend decisions using a direct proxy for the information asymmetry between managers and outside investors. Second, it focuses on a firm's ability to raise capital, which may affect its dividend policy. The relationship between information asymmetry and dividend payouts may vary depending on the firms' financial environments. When information asymmetry makes it difficult for firms to raise capital, financially constrained firms may find it harder to raise capital than nonconstrained firms. The management of such firms may seek to reduce information asymmetry through dividend payouts and, thus, facilitate future capital raising. Conversely, they may try to hold internal capital to prepare for future investment. Thus, this study analyzes the effect of information asymmetry on corporate dividend yields and investigates whether this effect depends on the firm's risk, financial constraints, and stock liquidity.

This study expands on previous research in several ways. First, earlier studies used firm size [10-12], comparisons between firms presumed to have different levels of information asymmetry [13,14], deviations in profit levels predicted by analysts [15], or public market conditions [9] as proxy variables for firms' information asymmetry. This study employs direct information asymmetry variables calculated using the Glosten-Harris $(G H)$ and Hasbrouk-Foster-Viswanathan (HFV) models, which are examined in the context of market microstructure, thereby clarifying the relationship between information asymmetry and dividend policies. Second, this study empirically analyzes how firms' financing environments affect the relationship between information asymmetry and dividends. This perspective and the related empirical tests are both rare in the literature. Third, the results of this study support the pecking order theory by showing that firms display a significant and negative relationship between dividend payouts and information asymmetry when they have difficulty raising external capital or when their cost of raising capital is high.

The remainder of this study is structured as follows. Section 2 reviews related studies and presents our hypotheses. Section 3 describes the study's sample data and key variables. Section 4 presents the results of the empirical analysis. Finally, Section 5 concludes this study.

\section{Literature Review and Development of Hypotheses}

\subsection{Dividends and Investor Reactions}

Corporate managers are unwilling to cut dividends because of likely investor reactions [16,17]. Baker et al. [18] found, through surveys, that corporate managers regard future profit levels and past propensity to pay dividends as critical factors in dividend decisions and consider shareholder demand for dividends as something they need to accommodate. Charest [4] and Michealy et al. [19] pointed out that adverse investor reactions make corporate managers reluctant to cut dividends. Meanwhile, Lang and Litzenberger [20] found that reactions to dividend changes made by firms with low Tobin's $Q$ are four times greater than those to dividend changes made by firms with high Tobin's $Q$. These results suggest that firms' dividend policies take investor reactions into consideration.

\subsection{Dividends and Agency Problems}

La Porta et al. [21] regard dividends as a way for outside shareholders to exercise pressure on corporate insiders to accumulate cash. Easterbrook [22] argues that firms pay dividends because of agency problems between corporate managers and shareholders. Managers need to make a sustained effort to pay a certain amount of dividends continuously. The lack of internal capital due to dividend payout motivates managers to resort to external capital, which allows financial institutions to monitor firms' financial standing and management activities. This can alleviate agency problems between corporate managers and outside shareholders. Additionally, Jensen [23] posits that highly-free cash flows are likely to lead to agency problems; therefore, firms would attempt to collect cashback through dividends [24]. Based on this literature, we can predict that agency problems have a positive effect on dividend levels and are attributable to information asymmetry between managers and outside investors. 


\subsection{Dividend Policy and Information Asymmetry}

Dewenter and Warther [13] found that Japanese keiretsu firms display lower information asymmetry than their American counterparts and that Japanese firms' share prices are less sensitive to dividend levels, which, in turn, are firmly tied to changes in earnings. This implies that firms featuring information asymmetry between managers and outside investors may display rigidity in their dividend policies due to a fear of investor reactions. Dividend payouts may reduce the information asymmetry between managers and outside investors [1]. A firm's information asymmetry level may correlate positively with dividend payouts and negatively with dividend cuts [13,25]. However, several studies do not support the signaling theory $[15,25]$. Deshmukh $[25]$ showed that dividend initiation has a negative relationship with information asymmetry. Kim and Kim [9] argue that information asymmetry may correlate positively or negatively with dividends depending on the firm's characteristics. Therefore, the effects of information asymmetry on firms' dividend policies warrant more in-depth investigation.

\subsection{Pecking Order Theory Hypothesis}

Myers and Majluf [7] proposed a "pecking order" theory, which posits that firms prefer internal financing to external financing. Managers have more accurate information about their firms than outside investors have. When information asymmetry is severe, it is difficult for a company to raise external capital by issuing new shares. Therefore, the pecking order theory predicts that firms with a high degree of information asymmetry are reluctant to pay dividends to hold internal capital. Deshmukh [8] shows that information asymmetry has a negative effect on dividends. Kim and Kim [9] show that firms listed on the Korea Securities Dealers Association Automated Quotation (KOSDAQ) have an incentive to mitigate information asymmetry through dividend policy, whereas firms listed on the Korea Composite Stock Price Index (KOSPI) have an incentive to increase internal capital by reducing dividends when they feature information asymmetry. Therefore, the greater the firm's information asymmetry, the more likely it is to reduce dividends to use internal capital. We, therefore, propose the following:

Hypothesis 1 (H1). The greater a company's information asymmetry, the more likely it is to reduce its dividends.

Firms with high external financing costs are more likely to prefer internal financing. The cost of external capital (or required rate of return) consists of risk-free returns and risk premiums. All other conditions being equal, firms featuring severe information asymmetry between corporate managers and outside investors are more difficult for investors to evaluate accurately than firms with lower information asymmetry. When a firm features such information asymmetry, the outside investors may demand higher returns as compensation for the inaccurate information. In other words, if a high-risk firm shows severe information asymmetry, the risk perceived by investors will increase both in terms of the company's own systematic risk and in terms of information risk. Therefore, firms with both a high beta and severe information asymmetry will prefer internal capital. We thus propose the following:

Hypothesis 2 (H2). The negative effect of information asymmetry on dividend payout is stronger for firms with high systematic risk.

\subsection{Competing Hypotheses: Signaling Effects of Dividends}

Miller and Rock [1] proposed a signaling hypothesis and found that in the real market, with information costs, firms' dividend payouts may serve to convey inside information to investors. They show that managers determine the extent of the payout, which cannot be easily replicated by competitors, to display that their position is stronger than the latter's. Bhattacharya [2] argues that due to this signaling effect of dividends, firms pay 
dividends despite the tax disadvantages because investors view them as a signal of expected cash flows.

Outside investors will recognize that firms displaying comparatively high information asymmetry carry high information risk and a high possibility of agency problems. Therefore, the managers of these firms are likely to want to deliver information to investors. If a dividend policy can alleviate information asymmetry and if managers consider this effect of dividends, they will likely decide to pay more dividends than the managers of firms with less information asymmetry. Investors demand dividend payouts in order to alleviate agency problems [22,23], and corporate managers pay dividends in order to deliver positive messages to investors $[1,26]$. Therefore, information asymmetry will have a positive effect on dividend levels. We thus propose the following:

Hypothesis 3 (H3). The level of information asymmetry has a positive effect on firms' dividend levels.

\section{Data and Methodology}

\subsection{Data}

Our sample consisted of 1238 firms listed on the Korea Exchange (KRX) and KOSDAQ from 2002 to 2010. We used this sample period for two reasons. First, to resolve the 2000 International Monetary Fund crisis that grew out of the 1997-98 Asian financial crisis, Korea introduced a fair disclosure system in 2002 to solve the information asymmetry problem in the securities market. Second, the GH and HFV variables used in this study were obtained from the data of listed companies up to 2010. The baseline data for the financial variables came from TS2000. After excluding companies that lack the data necessary for analysis, we had 6290 observations. To rule out outlier effects, we winsorize the values of the control variables at the $1 \%$ and $99 \%$ levels.

\subsection{Variables}

\subsubsection{Asymmetric Information}

Previous studies have measured information asymmetry using corporate accounting data, such as firm size [11,12,27], number of analysts following the firm [10], deviations from analysts' earnings forecasts [15], intangible assets [28], and free cash flows [23]. The effects of information asymmetry on dividend policies have been examined by comparing public and private firms based on the premise that degrees of information asymmetry differ between specific firm groups [14]. By contrast, this study measures firms' information asymmetry levels using the market microstructural models suggested by Glosten and Harris [29], Hasbrouck [30], and Foster and Viswanathan [31], thus ensuring that our estimation is more direct and refined than the estimations performed via other methods.

The links made between a firm's information asymmetry and dividend policies are generally premised on the view that information is asymmetrical between corporate managers and shareholders, and dividends are considered to play a role in mitigating agency problems and in delivering inside firm information to the market. The information asymmetry variables used in this study are based on the information asymmetry between insiders and outsiders, which can be interpreted as the information asymmetry between corporate managers and outside shareholders. Therefore, these variables are suitable for use in determining the effects of information asymmetry levels on dividend policies. We aim to observe how information asymmetry measured using these models affects dividend policies. The study's variables measure information asymmetry by assuming that what is not predictable among the determining factors for quoted spreads and order flow reflects the information asymmetry caused by inside information. Glosten and Milgrom [32] showed theoretically that the quoted spread results from information asymmetry and found that what connects buyers and sellers has a low trading volume and is a tricky issue for small-cap firms. They also argue that the key is the presence of insiders among traders, which leads investors to avoid trading. Accordingly, they showed that the quoted 
spread is caused by the reactions of investors who have no information when trading is conducted and who, therefore, use the information obtained from insiders. We used GH and $H F V$, information asymmetry variables, drawn from Glosten and Milgrom [32], which are considered to be related to information asymmetry in the realm of corporate finance. Based on the data for Korean firms with available GH and HFV values, the correlation coefficient between the two variables was 0.89 , which is substantial; this indicates that the observed values of the two models of Glosten and Milgrom [32] are accurate estimates of firms' information asymmetry levels.

\section{GH Model}

The GH model posits that the quoted spread is related to information asymmetry, as studies on market microstructures have indicated that market makers widen the quoted spread when they cannot distinguish between informed and uninformed traders and must prepare against the risk of damage caused by informed traders [29,32]. We empirically analyzed quoted spread and dissected it into the cost associated with information asymmetry, which has permanent effects, and temporary components reflecting order-processing and holding costs. Brennan and Subrahmanyam [33] devised the following estimation model by combining the model of Glosten and Harris [29] with that of Kyle [34]. According to the Kyle [34] model, $m_{t}$, the expected value of a stock at the information level at time $t$, can be articulated as follows:

$$
\mathrm{m}_{\mathrm{t}}=\mathrm{m}_{\mathrm{t}-1}+\lambda_{1} \mathrm{~V}_{\mathrm{t}}+\epsilon_{\mathrm{t}}
$$

In the Equation above, $\lambda_{1} V_{t}$ is the cost of information asymmetry; $V_{t}$ is the trading volume indicated in trading directions (positive [+] for buy and negative [[-] for sell) at each time $t$, and $\epsilon_{t}$ is a signal of public information. Specifically, $\lambda_{1} V_{t}$ is the variable cost estimated to have a certain value during a given period because $\lambda_{1} V_{t}$, which is the total shock from one trading on the price, changes in size according to the trading volume at time $t$; thus, $V_{t}$. In other words, if the trading volume at time $t$, or $V_{t}$, rises, the shock of that trading on the price increases along with it. Therefore, the changes in expected values due to stock information are $\Delta \mathrm{m}_{\mathrm{t}}=\lambda_{1} \mathrm{~V}_{\mathrm{t}}+\epsilon_{\mathrm{t}}$. Here, the shock on the price due to private information is $\lambda_{1} V_{t}$, or the cost of information asymmetry, and $\lambda_{1}$ refers to the cost of the shock on the price due to information asymmetry per share. Meanwhile, trading price, $\mathrm{P}_{\mathrm{t}}$, represents the case where trading is temporarily concluded at a price point outside the range of the stock's expected values and is articulated as follows:

$$
\mathrm{P}_{\mathrm{t}}=\mathrm{m}_{\mathrm{t}}+\psi_{1} \Omega_{\mathrm{t}}
$$

In Equation (2), $\psi_{1}$ refers to a temporary price shock, and $\Omega_{\mathrm{t}}$ is an indicator variable for trading direction. The value is -1 if, based on past trading directions, the transaction is seller-initiated and 1 if it is buyer-initiated. Here, $\psi_{1}$ is a fixed cost, as it does not fluctuate along with trading volume but is constant for a given level of trading. By combining Equations (1) and (2), the Glosten and Harris [28] model is deduced as follows:

$$
\Delta \mathrm{P}_{\mathrm{t}}=\lambda_{1} \mathrm{~V}_{\mathrm{t}}+\psi_{1}\left(\Omega_{\mathrm{t}}-\Omega_{\mathrm{t}-1}\right)+\epsilon_{\mathrm{t}}
$$

where $\lambda_{1}$ refers to the cost resulting from the information asymmetry risk with permanent effects, and $\psi_{1}$ is a temporary component of spread reflecting order-processing and other costs. Therefore, we define $\lambda_{1}$ in the GH model as the information asymmetry cost and use it as a gauge of information asymmetry. 


\section{HFV Model}

Another gauge of information asymmetry used in this study is based on the theses of Hasbrouck [29] and Foster and Viswanathan [30] and is proposed by Brennan and Subrahmanyam [32]. It is expressed as follows:

$$
\begin{gathered}
\mathrm{V}_{\mathrm{t}}=\alpha_{\mathrm{q}}+\sum_{\mathrm{i}=1}^{5} \beta_{\mathrm{i}} \Delta \mathrm{P}_{\mathrm{t}-\mathrm{i}}+\sum_{\mathrm{i}=1}^{5} \gamma_{\mathrm{i}} \Delta \mathrm{V}_{\mathrm{t}-\mathrm{i}}+\tau_{\mathrm{t}} \\
\Delta \mathrm{P}_{\mathrm{t}}=\alpha_{\mathrm{q}}+\psi_{2} \Delta \Omega_{\mathrm{t}}+\lambda_{2} \tau_{\mathrm{t}}+\epsilon_{\mathrm{t}}
\end{gathered}
$$

In the first Equation, $\mathrm{V}_{\mathrm{t}}$ refers to trading volume in the form of trading direction at time $t$ (positive $[+]$ for buy, negative [[-] for sell), and $\Omega_{t}$ is an indicator variable for trading direction. Hasbrouck [30] hypothesized that a significant portion of order flow could be predicted, noting the phenomenon wherein orders turn out to be correlated. He used a VAR model to show the amount of private information contained in trading through the unpredictable portion of order flow. Specifically, the first regression model was designed to identify the component in the order flow $\mathrm{V}_{\mathrm{t}}$ that cannot be explained by the preceding order flows or price changes. The residual of this first Equation, $\tau_{t}$, is the unpredictable portion of the order flow and is used as a proxy for private information to estimate the second regression model. This second regression model is the same as the GH model, except that $V_{t}$ is replaced by $\tau_{t}$. Therefore, the coefficient $\psi_{2}$, in front of $\Delta \Omega_{t}$, can be considered the component of temporary spread costs, such as order-processing costs, and the coefficient $\lambda_{2}$, in front of $\tau_{t}$, can be considered the cost incurred by information asymmetry. We use these models to explore how information asymmetry affects dividend policies by taking $\lambda_{2}$ as a gauge of $H F V$, a variable for information asymmetry.

\subsubsection{Beta Coefficient}

The beta coefficient is the risk drawn from the equity asset pricing model [35]; in statistical terms, it refers to the ratio of the covariance of individual stocks and market portfolios to the variance of market portfolios. Firms with a high beta coefficient will be perceived as a risky investment by investors due to either systemic risk or the risk associated with fluctuations in market valuations. Several studies have examined dividend disclosures and beta coefficients under the hypothesis that the market will reevaluate the risk associated with a firm's stock if the firm delivers information on its risk-free cash flows.

Charest [4] revealed that changes in beta associated with dividend increases are not clear-cut but that disclosures on dividend cuts raise the beta. Dielman and Oppenheimer [5] found that the beta decreases upon the resumption of, or amid a significant surge in, dividend payout but that only the resumption of dividend payout is statistically significant; furthermore, the beta increases upon the disclosure of no dividend payout or with a significant reduction in dividend payout. Thus, studies have empirically proven that the beta changes under the condition in which dividends deliver information about a firm's risk-free cash flows and the market reevaluates the risk associated with the stock. Carroll and Sear [6] empirically found that the beta changes to a greater extent under the influence of its size before disclosure occurs than it does under the influence of the information delivered through dividend disclosures themselves. This finding implies that the size of the beta before dividend disclosure is a factor explaining its changes following disclosure.

Among theoretical studies on the beta coefficient and the characteristics of firm assets, Hamada [36] found that the beta coefficient includes financial and operating leverages. Bowman [37] studied the theoretical relationships between systemic risk and financial variables and proved, in theory, that although the beta coefficient includes financial and operating leverages, it is unrelated to profit variability, growth potential, firm size, or dividend policies. However, Bowman pointed out that an empirical analysis of the relationship between the beta and the propensity to pay dividends demonstrates a significant relationship between the two while emphasizing that the gap between the theoretical models and empirical analyses needs to be kept in mind. In another study on asset characteristics and the beta coefficient, Brenner and Smidt [38] argued that the beta coefficient represents a 
risk-per-asset unit; they modified the single-term capital asset pricing model into a multiterm model and discovered an inverse relationship between the beta and asset value. Specifically, they found that changes in asset characteristics alter asset values and that this change is reflected in the beta coefficient. They further found that the beta coefficient has a negative relationship with sales volume, a positive relationship with fixed cost, and either a positive or negative relationship with the covariance of market fluctuations and sales volume, depending on the situation. Therefore, a large beta coefficient indicates significant financial and operating leverages. Other asset characteristics can be relevant in theory and can be more pronounced in practice. This supports the notion that firms with a high beta coefficient have poor financial standing.

\subsubsection{Dependent Variables and Control Variables}

Deshmukh [8] examined the effect of information asymmetry on dividend policy and uses dividend yield as a proxy for dividend payouts. Following Deshmukh [8], we used dividend yield as a dependent variable; it equals zero for non-dividend-paying firms. Dividends form part of firms' allocation policies and are dictated by investment policies.

We analyzed the relationship between firms' dividend policies and information asymmetry according to the financing cost. This study uses three variables that represent the level of a firm's risk, financial constraints, and liquidity of stocks related to the cost of capital. First, we used the beta coefficient as a proxy for firm risk. Second, we calculated the Kaplan and Zingales (KZ) index as a proxy for firms' financial constraints. Financially constrained firms find it more difficult or expensive to raise external capital than firms with lower financial constraints. We computed the KZ index following Lamont et al. [39] and Hadlock and Pierce [40]. Third, we used the turnover ratio of stocks as a proxy for stock liquidity, calculated by dividing the trading volume by the number of outstanding shares. The data on trading volume and number of outstanding shares were for December (the end of the fiscal year). Firms with high stock liquidity may reduce their financial constraints [41], but firms with low stock liquidity are required by investors to produce additional returns [42]. Butler et al. [43] suggested that liquid stock reduces the cost of raising capital.

In sum, we used three variables relating to the cost of raising capital. In our empirical setting, we used these variables as control variables and as categorical variables to analyze Hypothesis 2. We also used several other control variables. Table 1 presents the definitions of the variables.

Table 2 presents the statistics of all variables used in this study. The mean of DividendYield was 0.018182 . During the sample period, on average, investors were able to earn a return of $1.8 \%$ on the stock price through cash dividends. We also found that, on average, $42.75 \%$ of the sample firms' assets comprised debt.

Our main concern is whether the relationship between information asymmetry and dividend payouts varies depending on the cost of raising capital. The basic statistics for each variable are summarized in Table 2, along with the basic statistics for each risk group according to the beta coefficient. The beta coefficient is used as a proxy variable for a firm's risk level; however, the beta coefficient is under-researched and suffers from practical constraints in terms of estimation, so it cannot be considered to represent risk level directly. This means that it is not possible to set a specific high-risk level benchmark. We, therefore, classified the top $30 \%$ of firms placed within three decimal places of the beta coefficient out of the 6290 firms into a "high-risk" group and classified the bottom 30\% of firms placed within three decimal places of the beta coefficient into a "low-risk" group. The firms" financial policies may depend on their risks. The mean of the high-risk group (column 5 of Table 2) can be compared to that of the low-risk group (column 4 of Table 2). The low-risk firms, on average, give investors a greater dividend yield than high-risk firms, and the firm size is small. Column 6 of Table 2 presents univariate comparisons of variables between low- and high-risk firms. 
Table 1. Variable definitions.

\begin{tabular}{|c|c|c|}
\hline & Variable & Definition \\
\hline \multirow{2}{*}{$\begin{array}{l}\text { Dependent } \\
\text { Variable }\end{array}$} & \multirow[t]{2}{*}{ DividendYield } & $\begin{array}{l}\text { (Cash dividends for common stocks in year } t / \text { number of outstanding shares at fiscal } \\
\text { year-end)/year-end share price. }\end{array}$ \\
\hline & & This variable is a proxy for the firm's dividend payout. \\
\hline \multirow{5}{*}{$\begin{array}{l}\text { Categorical } \\
\text { Variables }\end{array}$} & $\begin{array}{l}\text { EquityBeta } \\
\text { (Provided by } \\
\text { YONHAP } \\
\text { INFOMAX database) }\end{array}$ & $\begin{array}{l}\text { A proxy variable for risk used to empirically analyze the hypothesis that the relationship } \\
\text { between firms' dividend levels and information asymmetry depends on the firm's risk } \\
\text { level. It will show a negative relationship with dividend level and is used as a categorical } \\
\text { variable to represent the difference in dividend policies between high- and low-risk firms. }\end{array}$ \\
\hline & \multirow[b]{2}{*}{ KZIndex } & $-1.002($ Cashflow/K) + 0.283(Q) + 3.139(Debt/Capital) - 32.368(Div/K) - 1.315(Cash/K). \\
\hline & & $\begin{array}{l}\text { This is a measure of firms' financial constraints. Financially constrained firms have } \\
\text { difficulty raising capital or find it expensive to do so. }\end{array}$ \\
\hline & \multirow[b]{2}{*}{$\begin{array}{l}\text { VolumeTurn } \\
\text { Over }\end{array}$} & Trading volume/number of outstanding shares. \\
\hline & & $\begin{array}{l}\text { This is a measure of the liquidity of stock. When a firm's stock has high liquidity, the firm } \\
\text { will be able to replace the demand for external financing by liquidating in part. Moreover, } \\
\text { highly liquid stocks incur low issuance costs. }\end{array}$ \\
\hline $\begin{array}{l}\text { Information } \\
\text { Asymmetry }\end{array}$ & GH, HFV & $\begin{array}{l}\text { This is a measure of information asymmetry. Following the signaling view and pecking } \\
\text { order theories, information asymmetry may have a negative or positive relationship with } \\
\text { dividend yield. }\end{array}$ \\
\hline \multirow{22}{*}{$\begin{array}{l}\text { Control } \\
\text { Variables }\end{array}$} & \multirow{2}{*}{ Size } & In (year-end share price in year $\mathrm{t} \times$ number of outstanding shares). \\
\hline & & This is used as a variable to control for the size effect. \\
\hline & \multirow[b]{2}{*}{ DebtRatio } & Debt/total assets. \\
\hline & & $\begin{array}{l}\text { Due to burdens associated with fixed costs and bankruptcy risk, firms with a high debt } \\
\text { ratio are reluctant to pay out dividends. }\end{array}$ \\
\hline & \multirow[b]{2}{*}{ Collateral } & Tangible assets/total assets. \\
\hline & & $\begin{array}{l}\text { Firms with a high fraction of tangible assets find it easy to finance debt [44]. Firms with a } \\
\text { high debt capacity are likely to pay dividends. }\end{array}$ \\
\hline & \multirow{2}{*}{ BookToMarket } & Book value of equity/(year-end share price in year $\mathrm{t} \times$ number of outstanding shares). \\
\hline & & This is used as a variable to control for the value effect. \\
\hline & \multirow[b]{2}{*}{ Profitability } & Current net income/assets. \\
\hline & & $\begin{array}{l}\text { Higher profitability means more disposable cash flow for dividends, so there is a positive } \\
\text { relationship between profitability and dividends. Due to the information effects of } \\
\text { dividends under information asymmetry, dividends paid are hard for other firms to } \\
\text { replicate, so it has a positive relationship with dividends. }\end{array}$ \\
\hline & \multirow[b]{2}{*}{ FreeCashFlow } & (Cash flow from operating activities - interest expense + interest income)/total assets. \\
\hline & & $\begin{array}{l}\text { Firms with ample free cash flow are likely to pay dividends, and dividends can mitigate } \\
\text { firms' agency problems. The free cash flow variable may have a positive relationship with } \\
\text { dividend payout. }\end{array}$ \\
\hline & \multirow{2}{*}{ SalesGrowth } & Sales/sales. \\
\hline & & Firms with high sales growth are likely to pay dividends. \\
\hline & \multirow{2}{*}{ IncomeGrowth } & Operating income in year $\mathrm{t} /$ operating income. \\
\hline & & Firms with high operating income growth are likely to pay dividends. \\
\hline & \multirow{2}{*}{ Ownership } & $\begin{array}{l}\text { The common equity share of the largest shareholders and that of their special } \\
\text { relationships, such as family. }\end{array}$ \\
\hline & & $\begin{array}{l}\text { This variable is a proxy variable for firms' ownership concentration and has a negative } \\
\text { relationship with dividends in terms of agency problems. }\end{array}$ \\
\hline & \multirow{2}{*}{ Year } & Equal to 1 if a firm falls into a specific year and 0 otherwise. \\
\hline & & We create a year dummy variable to control for year fixed effects. \\
\hline & \multirow[b]{2}{*}{ Industry } & Equal to 1 if a firm falls into a specific industry and 0 otherwise. \\
\hline & & $\begin{array}{l}\text { We create industry dummy variables using the two-digit Korean Standard Industrial } \\
\text { Classification to control for industry fixed effects. }\end{array}$ \\
\hline
\end{tabular}


Table 2. Sample characteristics.

\begin{tabular}{cccccc}
\hline & \multicolumn{2}{c}{ Full Sample } & \multicolumn{2}{c}{ Sub-Sample by Equity Beta } \\
\cline { 2 - 6 } & Mean & Median & Low 30\% & High 30\% & Diff. Mean \\
\hline DividendYield & 0.018182 & 0.012226 & 0.02489 & 0.011105 & $0.013785^{* * *}$ \\
GH & 0.047442 & 0.00224 & 0.053186 & 0.042085 & 0.011101 \\
HFV & 0.049633 & 0.002284 & 0.055189 & 0.043125 & 0.012064 \\
EquityBeta & 0.80632 & 0.78779 & 0.36197 & 1.27486 & $-0.91289^{* * *}$ \\
KZIndex & 0.23937 & 1.98573 & 1.64206 & -2.58409 & $4.22615^{*}$ \\
VolumeTurn Over & 0.39018 & 0.10244 & 0.31743 & 0.50665 & $-0.18922^{* * *}$ \\
Size & 25.1321 & 24.8104 & 24.6758 & 25.7009 & $-1.0251^{* * *}$ \\
DebtRatio & 0.42746 & 0.430194 & 0.39684 & 0.45520 & $-0.05836^{* * *}$ \\
Collateral & 0.32334 & 0.31231 & 0.34616 & 0.2997 & $0.04646^{* * *}$ \\
BookToMarket & 1.66313 & 1.30438 & 2.06023 & 1.20796 & $0.85227^{* * *}$ \\
Profitability & 0.021661 & 0.035523 & 0.02892 & 0.014386 & $0.014534^{* * *}$ \\
FreeCashFlow & 0.039839 & 0.039941 & 0.042013 & 0.035998 & $0.006015^{*}$ \\
SalesGrowth & 1.12679 & 1.07249 & 1.11302 & 1.16358 & $-0.05056^{* * *}$ \\
IncomeGrowth & 0.93523 & 0.95619 & 0.91461 & 0.92745 & -0.01284 \\
Ownership & 40.5295 & 39.87 & 45.7603 & 35.8028 & $9.9575^{* * *}$ \\
\hline
\end{tabular}

The variable definitions are given in Table 1 . There are 6290 observations in the full sample, and no variable has missing values. ${ }^{* * *} p<0.01, * p<0.1$.

\subsection{Methodology}

This study empirically analyzes the impact of information asymmetry on dividend yields. The dividend policy is determined at the end of the financial year or the beginning of the next year, depending on the firm's performance. Therefore, this study analyzes the impact of corporate characteristics on dividend decisions in year $t$. The regression model investigates the relationship between information asymmetry and the dividend yield, as follows:

$$
\begin{aligned}
\text { DividendYield }_{i, t} & =\beta_{0}+\beta_{1} \text { Inform Asym }_{i, t}+\beta_{2} \text { EquityBetan }_{i, t} \\
& +\beta_{3} \text { KZ Index }_{i, t}+\beta_{4} \text { VolumeTurnover }_{i, t} \\
& +\gamma \text { Controlvaiables }_{i, t}+\varphi \text { Year and industry Dummy } \\
& +\epsilon_{i, t}
\end{aligned}
$$

The pecking order theory (Hypothesis 1) predicts that the coefficient of the information asymmetry variable (Inform Asym) is negative and significant in Equation (5). However, the signaling view (alternative Hypothesis 3 ) predicts a positive relationship between information asymmetry and dividend payouts.

This study's second hypothesis predicts that the effect of information asymmetry on dividend yields is strong when the firms have a high systematic risk. We divided the samples into two groups based on the beta coefficient. In Equation (5), the coefficient of information asymmetry $\left(\beta_{1}\right)$ is expected to be more negative when the samples are in the high-risk group. Furthermore, two more categorical variables were used to determine whether the relationship between information asymmetry and dividend policies differs depending on the firm's ability to raise capital. The pecking order theory posits a negative relationship between information asymmetry and dividend yield. In this case, the impact of information asymmetry should be more significant in groups with severe financial commitments or low liquidity in stocks.

\section{Results and Discussion}

\subsection{Firms' Information Asymmetry and Dividend Levels}

Table 3 reports the regression results on how information asymmetry affects corporate dividend payouts. Dividend yield is used as the dependent variable. In Model (1) of Table 3, the coefficient of the information asymmetry between managers and outside investors (i.e., $G H$ and $H F V$ ) was -0.00103 and statistically significant at the $1 \%$ level. 
Model (1) did not use control variables. This study used nine variables reflecting baseline financial characteristics and added three variables reflecting firms' financing environments. Model (3) of Table 3 used 13 independent variables, including GH. The coefficient of GH (i.e., InformationAsym) was -0.0018 and statistically significant at the $1 \%$ level. The regression results using $H F V$ were similar to those using GH. This study also found that the model using all the control variables had better goodness-of-fit and explanatory power (i.e., adjusted R-square). In Models (3) and (6) of Table 3, the effects of the control variables on dividend payouts were similar. Corporate risk (Beta) and the liquidity of stock (VolumnTurnOver) had a negative relationship with dividend payout, consistent with our expectations regarding the cost of raising capital.

Table 3. Firms' information asymmetry and dividend levels.

\begin{tabular}{|c|c|c|c|c|c|c|}
\hline & \multicolumn{3}{|c|}{$G H$} & \multicolumn{3}{|c|}{$H F V$} \\
\hline & (1) & (2) & (3) & (4) & (5) & (6) \\
\hline InformAsym & $\begin{array}{c}-0.00103^{* * *} \\
(0.00027)\end{array}$ & $\begin{array}{c}-0.00179^{* * *} \\
(0.00034)\end{array}$ & $\begin{array}{c}-0.0018^{* * *} \\
(0.00038)\end{array}$ & $\begin{array}{c}-0.00106^{* * *} \\
(0.00025)\end{array}$ & $\begin{array}{c}-0.00181^{* * *} \\
(0.00032)\end{array}$ & $\begin{array}{c}-0.00182 * * * \\
(0.00036)\end{array}$ \\
\hline EquityBeta & & & $\begin{array}{c}-0.0061^{* * *} \\
(0.0006)\end{array}$ & & & $\begin{array}{c}-0.0061^{* * *} \\
(0.0006)\end{array}$ \\
\hline KZIndex & & & $\begin{array}{l}-0.00001 \\
(0.00001)\end{array}$ & & & $\begin{array}{l}-0.00001 \\
(0.00001)\end{array}$ \\
\hline VolumeTurnOver & & & $\begin{array}{c}-0.00098^{* * *} \\
(0.00015)\end{array}$ & & & $\begin{array}{c}-0.00098^{* * *} \\
(0.00015)\end{array}$ \\
\hline Size & & $\begin{array}{c}-0.0012^{* * *} \\
(0.00016)\end{array}$ & $\begin{array}{c}-0.00086^{* * *} \\
(0.00017)\end{array}$ & & $\begin{array}{c}-0.00119 * * * \\
(0.00016)\end{array}$ & $\begin{array}{c}-0.00085^{* * *} \\
(0.00017)\end{array}$ \\
\hline DebtRatio & & $\begin{array}{c}-0.0127^{* * *} \\
(0.00137)\end{array}$ & $\begin{array}{c}-0.01093^{* * *} \\
(0.00137)\end{array}$ & & $\begin{array}{c}-0.01272 \text { *** } \\
(0.00137)\end{array}$ & $\begin{array}{c}-0.01095^{* * *} \\
(0.00137)\end{array}$ \\
\hline Collateral & & $\begin{array}{c}-0.00159 \\
(0.0014)\end{array}$ & $\begin{array}{c}-0.00207 \\
(0.0014)\end{array}$ & & $\begin{array}{c}-0.00159 \\
(0.0014)\end{array}$ & $\begin{array}{c}-0.00206 \\
(0.0014)\end{array}$ \\
\hline BookToMarket & & $\begin{array}{c}0.00178 * * * \\
(0.00025)\end{array}$ & $\begin{array}{c}0.00156^{* * *} \\
(0.00025)\end{array}$ & & $\begin{array}{c}0.00178 * * * \\
(0.00025)\end{array}$ & $\begin{array}{c}0.00156^{* * *} \\
(0.00025)\end{array}$ \\
\hline Profitability & & $\begin{array}{l}0.0369 * * * \\
(0.00265)\end{array}$ & $\begin{array}{c}0.03681^{* * *} \\
(0.00264)\end{array}$ & & $\begin{array}{c}0.03691 * * * \\
(0.00265)\end{array}$ & $\begin{array}{c}0.03682 * * * \\
(0.00264)\end{array}$ \\
\hline FreeCashFlow & & $\begin{array}{c}0.03081^{* * *} \\
(0.00281)\end{array}$ & $\begin{array}{c}0.02821^{* * *} \\
(0.00279)\end{array}$ & & $\begin{array}{c}0.03079 * * * \\
(0.00281)\end{array}$ & $\begin{array}{c}0.02819 * * * \\
(0.00279)\end{array}$ \\
\hline SalesGrowth & & $\begin{array}{l}-0.00047 \\
(0.00048)\end{array}$ & $\begin{array}{l}-0.00031 \\
(0.00048)\end{array}$ & & $\begin{array}{l}-0.00048 \\
(0.00048)\end{array}$ & $\begin{array}{l}-0.00031 \\
(0.00048)\end{array}$ \\
\hline IncomeGrowth & & $\begin{array}{c}0.00033^{* * * *} \\
(0.00006)\end{array}$ & $\begin{array}{l}0.0003^{* * * *} \\
(0.00000)\end{array}$ & & $\begin{array}{c}0.00033^{* * *} \\
(0.00006)\end{array}$ & $\begin{array}{l}0.0003^{* * *} \\
(0.00000)\end{array}$ \\
\hline Ownership & & $\begin{array}{c}0.00018^{* * * *} \\
(0.00002)\end{array}$ & $\begin{array}{l}0.0001^{* * * *} \\
(0.00000)\end{array}$ & & $\begin{array}{c}0.00018^{* * *} \\
(0.00002)\end{array}$ & $\begin{array}{l}0.0001 * * * \\
(0.00000)\end{array}$ \\
\hline Year dummies & YES & YES & YES & YES & YES & YES \\
\hline $\begin{array}{l}\text { Industry } \\
\text { dummies }\end{array}$ & YES & YES & YES & YES & YES & YES \\
\hline $\mathrm{N}$ & 6290 & 6290 & 6290 & 6290 & 6290 & 6290 \\
\hline Adj. R-square & 0.1881 & 0.3315 & 0.346 & 0.1881 & 0.3316 & 0.3461 \\
\hline
\end{tabular}

All regressions used an adjusted-standard error for heteroscedasticity, and the values are reported in parentheses. $* * *$ denotes statistical significance at the $1 \%$.

This study proposed two competing hypotheses (H1 and H3), following the pecking order theory and the signaling view of dividends. Our results support the pecking order theory (H1): Firms with information asymmetry are likely to reduce dividend payouts in order to use internal capital.

\subsection{Dividend Payouts, Information Asymmetry, and Cost of Capital}

Table 4 reports the regression results on the effects of information asymmetry on corporate dividend payouts across the firms' risk-estimated beta coefficient. Dividend yield was used as the dependent variable. We divided the sample into two groups based 
on their beta coefficient to compare the high- and low-risk groups. The top- $20 \%$ beta group comprised the high-risk companies, and the bottom- $20 \%$ beta group comprised the low-risk companies, respectively (we further analyzed the high- and low-risk groups based on $30 \%$ and $50 \%$ thresholds, and the results were consistent with those found using groups based on the $20 \%$ threshold). Hypothesis 2 predicts that the negative effect of information asymmetry on dividend payout is greater for firms facing a high cost of raising capital. The cost increases along with the firms' risk because investors require higher returns on risky assets. Thus, risky firms with high information asymmetry have to pay higher costs when raising capital from outside investors or lenders. Therefore, they may prefer internal capital, and this preference is likely to result in a low dividend yield. Following Hypothesis 2, the coefficients of information asymmetry on corporate dividend yields are more negative and statistically significant for firms in the high-risk group.

Table 4. Effects of firm's information asymmetry on dividend policy by risk level (beta).

\begin{tabular}{|c|c|c|c|c|}
\hline & \multicolumn{2}{|c|}{$G H$} & \multicolumn{2}{|c|}{$H F V$} \\
\hline & $\begin{array}{l}\text { Low } 20 \% \\
\text { (1) }\end{array}$ & $\begin{array}{l}\text { High } 20 \% \\
\text { (2) }\end{array}$ & $\begin{array}{l}\text { Low } 20 \% \\
\text { (1) }\end{array}$ & $\begin{array}{l}\text { High } 20 \% \\
\text { (2) }\end{array}$ \\
\hline InformAsym & $\begin{array}{l}-0.00091 \\
(0.00088)\end{array}$ & $\begin{array}{c}-0.00106^{* * *} \\
(0.00034)\end{array}$ & $\begin{array}{c}-0.00094 \\
(0.00093)\end{array}$ & $\begin{array}{c}-0.00105^{* * *} \\
(0.00026)\end{array}$ \\
\hline EquityBeta & $\begin{array}{c}0.00753^{* *} \\
(0.00297) \\
\end{array}$ & $\begin{array}{l}-0.00132 \\
(0.00123)\end{array}$ & $\begin{array}{c}0.00753 * * \\
(0.00297)\end{array}$ & $\begin{array}{l}-0.00133 \\
(0.00123)\end{array}$ \\
\hline KZ Index & $\begin{array}{c}-0.00007^{* *} \\
(0.00003)\end{array}$ & $\begin{array}{c}0.00000^{* * * *} \\
(0.00000)\end{array}$ & $\begin{array}{c}-0.00007^{* *} \\
(0.00003)\end{array}$ & $\begin{array}{c}0.00000^{* * * *} \\
(0.00000)\end{array}$ \\
\hline $\begin{array}{l}\text { VolumeTurn } \\
\text { Over }\end{array}$ & $\begin{array}{c}-0.00079 * * \\
(0.00032)\end{array}$ & $\begin{array}{c}-0.00133^{* * *} \\
(0.00027)\end{array}$ & $\begin{array}{c}-0.00079 * * \\
(0.00032)\end{array}$ & $\begin{array}{c}-0.00133^{* * *} \\
(0.00027)\end{array}$ \\
\hline EquityBeta & $\begin{array}{c}-0.00297^{* * *} \\
(0.00061)\end{array}$ & $\begin{array}{c}-0.00004 \\
(0.00021)\end{array}$ & $\begin{array}{c}-0.00297^{* * *} \\
(0.00061)\end{array}$ & $\begin{array}{c}-0.00004 \\
(0.00021)\end{array}$ \\
\hline KZIndex & $\begin{array}{c}-0.01391 * * * \\
(0.00379)\end{array}$ & $\begin{array}{c}-0.00419 \text { ** } \\
(0.00193)\end{array}$ & $\begin{array}{c}-0.01392 * * * \\
(0.0038)\end{array}$ & $\begin{array}{c}-0.00421 * * \\
(0.00193)\end{array}$ \\
\hline $\begin{array}{c}\text { VolumeTurn } \\
\text { Over }\end{array}$ & $\begin{array}{l}-0.00259 \\
(0.00381)\end{array}$ & $\begin{array}{l}-0.00077 \\
(0.00198)\end{array}$ & $\begin{array}{l}-0.00257 \\
(0.00381)\end{array}$ & $\begin{array}{l}-0.00078 \\
(0.00198)\end{array}$ \\
\hline Size & $\begin{array}{l}0.00102 * \\
(0.00053)\end{array}$ & $\begin{array}{c}0.00221^{* * *} \\
(0.00048)\end{array}$ & $\begin{array}{l}0.00102 * \\
(0.00053)\end{array}$ & $\begin{array}{c}0.00221^{* * *} \\
(0.00048)\end{array}$ \\
\hline DebtRatio & $\begin{array}{c}0.04823^{* * *} \\
(0.00787)\end{array}$ & $\begin{array}{c}0.02749^{* * *} \\
(0.00324)\end{array}$ & $\begin{array}{c}0.04823^{* * *} \\
(0.00787)\end{array}$ & $\begin{array}{c}0.02752 * * * \\
(0.00324)\end{array}$ \\
\hline Collateral & $\begin{array}{c}0.05768^{* * * *} \\
(0.00844)\end{array}$ & $\begin{array}{l}0.00709 * * \\
(0.00356)\end{array}$ & $\begin{array}{c}0.05767^{* * *} \\
(0.00844)\end{array}$ & $\begin{array}{l}0.00706^{* *} \\
(0.00356)\end{array}$ \\
\hline BookToMarket & $\begin{array}{c}0.00175 \\
(0.00164)\end{array}$ & $\begin{array}{c}0.00046 \\
(0.00087)\end{array}$ & $\begin{array}{c}0.00175 \\
(0.00164)\end{array}$ & $\begin{array}{c}0.00045 \\
(0.00087)\end{array}$ \\
\hline Profitability & $\begin{array}{c}0.0002 \\
(0.00000)\end{array}$ & $\begin{array}{l}0.0003 * * \\
(0.00000)\end{array}$ & $\begin{array}{c}0.0002 \\
(0.00000)\end{array}$ & $\begin{array}{l}0.00030 * * \\
(0.00000)\end{array}$ \\
\hline FreeCashFlow & $\begin{array}{l}0.0002 * * * \\
(0.00000)\end{array}$ & $\begin{array}{l}0.0001 \text { *** } \\
(0.00000)\end{array}$ & $\begin{array}{l}0.0002 * * * \\
(0.00000)\end{array}$ & $\begin{array}{c}0.00010^{* * *} \\
(0.00000)\end{array}$ \\
\hline Year dummies & YES & YES & YES & YES \\
\hline $\begin{array}{l}\text { Industry } \\
\text { dummies }\end{array}$ & YES & YES & YES & YES \\
\hline $\mathrm{N}$ & 1258 & 1258 & 1258 & 1258 \\
\hline Adj. R-square & 0.3649 & 0.257 & 0.3649 & 0.2573 \\
\hline
\end{tabular}

All regressions used an adjusted-standard error for heteroscedasticity, and the values are reported in parentheses. $* * *, * *$, and $*$ denote statistical significance at the $1 \%, 5 \%$, and $10 \%$ levels, respectively. 
Table 5 reports the regression results on how the relationship between dividend yield and information asymmetry depends on financial constraints. This study used the KZ index, following Lamont et al. [39] and Hadlock and Pierce [40]. Financially constrained firms find it harder to raise capital than other firms do. Therefore, financially constrained firms featuring high information asymmetry are likely to prefer internal capital. Hypothesis 2 predicts that financially constrained firms with high information asymmetry give investors low dividend yields to hold internal capital. Among firms facing financial constraints, those with greater information asymmetry will find it more difficult to raise external capital. Therefore, following the pecking order theory, the negative effect of information asymmetry on dividend payout is particularly strong for financially constrained firms. We classified the samples according to the top and bottom $20 \%, 30 \%$, and $50 \%$, respectively, based on the $\mathrm{KZ}$ index values.

Table 5. Effects of firm's information asymmetry on dividend policy according to financial constraint.

\begin{tabular}{|c|c|c|c|c|c|c|}
\hline \multicolumn{7}{|c|}{ [Panel A: Result Using $G H$ ]. } \\
\hline & Low $20 \%$ & High $20 \%$ & Low $30 \%$ & High $30 \%$ & Low $50 \%$ & High $50 \%$ \\
\hline & (1) & (2) & (3) & (4) & (5) & (6) \\
\hline \multirow{2}{*}{$G H$} & 0.00979 & $-0.00231^{* * *}$ & -0.00204 & $-0.00399^{* * *}$ & $-0.00155^{* * *}$ & $-0.00229 * *$ \\
\hline & $(0.00992)$ & $(0.00086)$ & $(0.00259)$ & $(0.00114)$ & $(0.00038)$ & $(0.00091)$ \\
\hline \multirow{2}{*}{ EquityBeta } & $-0.00818^{* * *}$ & $-0.00289 *$ & $-0.00783^{* * *}$ & $-0.00316^{* * *}$ & $-0.00729 * * *$ & $-0.00437^{* * *}$ \\
\hline & $(0.00127)$ & $(0.00162)$ & $(0.00102)$ & $(0.00118)$ & $(0.00078)$ & $(0.00089)$ \\
\hline \multirow{2}{*}{ KZIndex } & -0.00001 & $-0.00007^{*}$ & $-0.00001 *$ & $-0.0001^{* *}$ & $-0.00001 *$ & $-0.00011^{* * *}$ \\
\hline & $(0.00001)$ & $(0.00004)$ & $(0.00001)$ & $(0.00004)$ & $(0.00001)$ & $(0.00004)$ \\
\hline \multirow{2}{*}{$\begin{array}{c}\text { VolumeTurn } \\
\text { Over }\end{array}$} & $-0.00291^{* * *}$ & $-0.00109^{* * *}$ & $-0.00211^{* * *}$ & $-0.00093^{* * *}$ & $-0.00156^{* * *}$ & $-0.00078^{* * *}$ \\
\hline & $(0.00057)$ & $(0.00019)$ & $(0.00045)$ & $(0.00017)$ & $(0.00029)$ & $(0.00018)$ \\
\hline \multirow{2}{*}{ Size } & $-0.00273^{* * *}$ & -0.00017 & $-0.00202^{* * *}$ & -0.00049 & $-0.0018^{* * *}$ & -0.00026 \\
\hline & (0.0004) & $(0.00056)$ & (0.00029) & $(0.00042)$ & $(0.00022)$ & $(0.00027)$ \\
\hline \multirow{2}{*}{ DebtRatio } & $0.00741^{* *}$ & $-0.02938^{* * *}$ & $0.00831^{* * *}$ & $-0.02488^{* * *}$ & $0.00554^{* * *}$ & $-0.01416^{* * *}$ \\
\hline & $(0.00366)$ & $(0.00471)$ & $(0.00293)$ & $(0.00379)$ & $(0.00212)$ & $(0.00253)$ \\
\hline \multirow{2}{*}{ Collateral } & $0.0245^{* * *}$ & -0.00387 & $0.00721^{* *}$ & -0.00319 & 0.00111 & -0.00263 \\
\hline & $(0.0056)$ & $(0.00342)$ & $(0.00346)$ & $(0.00273)$ & $(0.00204)$ & $(0.00206)$ \\
\hline \multirow{2}{*}{ BookToMarket } & $0.00234^{* *}$ & $0.00127^{* * *}$ & $0.00315^{* * *}$ & $0.00104^{* * *}$ & $0.00329^{* * *}$ & $0.00154^{* * *}$ \\
\hline & $(0.00094)$ & $(0.00041)$ & $(0.00079)$ & $(0.00036)$ & $(0.00053)$ & $(0.00029)$ \\
\hline \multirow{2}{*}{ Profitability } & $0.03761^{* * *}$ & $0.03797^{* * *}$ & $0.04333^{* * *}$ & $0.0355^{* * *}$ & $0.04403^{* * *}$ & $0.03516^{* * *}$ \\
\hline & $(0.00566)$ & $(0.00622)$ & $(0.00526)$ & $(0.00476)$ & $(0.00349)$ & $(0.00355)$ \\
\hline \multirow{2}{*}{ FreeCashFlow } & $0.02076^{* * *}$ & $0.03045^{* * *}$ & $0.02141^{* * *}$ & $0.03562^{* * *}$ & $0.02262 * * *$ & $0.02897^{* * *}$ \\
\hline & $(0.00616)$ & $(0.0075)$ & $(0.00503)$ & $(0.00589)$ & $(0.00365)$ & $(0.00418)$ \\
\hline \multirow{2}{*}{ SalesGrowth } & -0.00096 & 0.00041 & -0.00116 & 0.00014 & $-0.00178^{* * *}$ & 0.00088 \\
\hline & $(0.00115)$ & $(0.00141)$ & $(0.00096)$ & $(0.00106)$ & $(0.00063)$ & $(0.0008)$ \\
\hline \multirow[b]{2}{*}{ IncomeGrowth } & 0.00020 & $0.0005^{* * *}$ & $0.0003 *$ & $0.0003^{* *}$ & $0.0002 * *$ & $0.0004^{* * *}$ \\
\hline & $(0.00000)$ & $(0.00000)$ & $(0.00000)$ & $(0.00000)$ & $(0.00000)$ & $(0.00000)$ \\
\hline \multirow{2}{*}{ Ownership } & $0.00010^{* * *}$ & $0.0002^{* * *}$ & $0.0002^{* * *}$ & $0.0002^{* * *}$ & $0.0001^{* * *}$ & $0.0001^{* * *}$ \\
\hline & $(0.00000)$ & $(0.00000)$ & $(0.00000)$ & $(0.00000)$ & $(0.00000)$ & $(0.00000)$ \\
\hline \multirow{3}{*}{$\begin{array}{c}\text { Year dummies } \\
\text { Industry } \\
\text { dummies } \\
\mathrm{N}\end{array}$} & YES & YES & YES & YES & YES & YES \\
\hline & YES & YES & YES & YES & YES & YES \\
\hline & 1258 & 1258 & 1887 & 1887 & 3145 & 3145 \\
\hline Adj. R-square & 0.4555 & 0.3292 & 0.4159 & 0.3377 & 0.397 & 0.3377 \\
\hline
\end{tabular}


Table 5. Cont.

\begin{tabular}{|c|c|c|c|c|c|c|}
\hline \multicolumn{7}{|c|}{ [Panel B: Result Using HFV] } \\
\hline & Low 20\% & High $20 \%$ & Low $30 \%$ & High $30 \%$ & Low 50\% & High $50 \%$ \\
\hline & (1) & (2) & (3) & (4) & (5) & (6) \\
\hline \multirow{2}{*}{ Intercept } & $0.07734^{* * *}$ & 0.01313 & $0.05934^{* * *}$ & $0.02224^{* *}$ & $0.05747^{* * *}$ & 0.00974 \\
\hline & $(0.01093)$ & $(0.01389)$ & $(0.00852)$ & $(0.01107)$ & $(0.00662)$ & $(0.00759)$ \\
\hline \multirow{2}{*}{$H F V$} & 0.00973 & $-0.00232^{*}$ & -0.00239 & $-0.00477^{* * *}$ & $-0.00152 * * *$ & $-0.00244^{* *}$ \\
\hline & $(0.00972)$ & $(0.00121)$ & $(0.0025)$ & $(0.0014)$ & $(0.00035)$ & $(0.00103)$ \\
\hline \multirow{2}{*}{ EquityBeta } & $-0.00818^{* * *}$ & $-0.00287^{*}$ & $-0.00785^{* * *}$ & $-0.00316^{* * *}$ & $-0.00729 * * *$ & $-0.00436^{* * *}$ \\
\hline & $(0.00127)$ & $(0.00162)$ & $(0.00102)$ & $(0.00118)$ & $(0.00077)$ & $(0.00089)$ \\
\hline \multirow{2}{*}{ KZIndex } & -0.00001 & $-0.00007 *$ & $-0.00001 *$ & $-0.0001^{* *}$ & $-0.00001 *$ & $-0.00011^{* * *}$ \\
\hline & (0.00001) & $(0.00004)$ & $(0.00001)$ & $(0.00004)$ & (0.00001) & $(0.00004)$ \\
\hline \multirow{2}{*}{$\begin{array}{c}\text { VolumeTurn } \\
\text { Over }\end{array}$} & $-0.00291^{* * *}$ & $-0.00109^{* * *}$ & $-0.00212 * * *$ & $-0.00094^{* * *}$ & $-0.00156^{* * *}$ & $-0.00078^{* * *}$ \\
\hline & $(0.00057)$ & $(0.00019)$ & $(0.00045)$ & $(0.00017)$ & $(0.00029)$ & $(0.00018)$ \\
\hline \multirow{2}{*}{ Size } & $-0.00273^{* * *}$ & -0.00017 & $-0.00202^{* * *}$ & -0.00048 & $-0.0018^{* * *}$ & -0.00026 \\
\hline & (0.00039) & $(0.00056)$ & $(0.00029)$ & $(0.00042)$ & $(0.00022)$ & $(0.00027)$ \\
\hline \multirow{2}{*}{ DebtRatio } & $0.0074 * *$ & $-0.02935^{* * *}$ & $0.0083^{* * *}$ & $-0.02494^{* * *}$ & $0.00551 * * *$ & $-0.01418 * * *$ \\
\hline & $(0.00366)$ & $(0.00471)$ & $(0.00293)$ & $(0.00379)$ & $(0.00212)$ & $(0.00253)$ \\
\hline \multirow{2}{*}{ Collateral } & $0.02453^{* * *}$ & -0.00386 & $0.00722 * *$ & -0.00308 & 0.00111 & -0.0026 \\
\hline & $(0.00561)$ & $(0.00342)$ & $(0.00346)$ & $(0.00273)$ & $(0.00204)$ & $(0.00206)$ \\
\hline \multirow{2}{*}{ BookToMarket } & $0.00235^{* *}$ & $0.00127^{* * *}$ & $0.00316^{* * *}$ & $0.00104^{* * *}$ & $0.00329 * * *$ & $0.00154^{* * * *}$ \\
\hline & $(0.00094)$ & $(0.00041)$ & (0.00079) & $(0.00036)$ & $(0.00053)$ & $(0.00029)$ \\
\hline \multirow{2}{*}{ Profitability } & $0.0376^{* * *}$ & $0.03799 * * *$ & $0.04331^{* * *}$ & $0.0355^{* * *}$ & $0.04403 * * *$ & $0.03516^{* * *}$ \\
\hline & $(0.00566)$ & $(0.00622)$ & $(0.00526)$ & $(0.00476)$ & $(0.00349)$ & $(0.00355)$ \\
\hline \multirow{2}{*}{ FreeCashFlow } & $0.02074^{* * *}$ & $0.03046^{* * *}$ & $0.02144^{* * *}$ & $0.03562^{* * *}$ & $0.0226^{* * *}$ & $0.02898 * * *$ \\
\hline & $(0.00615)$ & $(0.0075)$ & $(0.00503)$ & $(0.00589)$ & $(0.00365)$ & $(0.00418)$ \\
\hline \multirow{2}{*}{ SalesGrowth } & -0.00096 & 0.00041 & -0.00116 & 0.00015 & $-0.00178^{* * *}$ & 0.00088 \\
\hline & $(0.00115)$ & $(0.00141)$ & $(0.00096)$ & $(0.00107)$ & $(0.00063)$ & $(0.0008)$ \\
\hline \multirow{2}{*}{ IncomeGrowth } & 0.0002 & $0.0005^{* * *}$ & 0.0003 * & $0.0003^{* *}$ & $0.0002 * *$ & $0.0004^{* * *}$ \\
\hline & $(0.00000)$ & $(0.00000)$ & $(0.00000)$ & $(0.00000)$ & $(0.00000)$ & $(0.00000)$ \\
\hline \multirow{2}{*}{ Ownership } & $0.0001 * * *$ & $0.0002^{* * *}$ & $0.0002 * * *$ & $0.0002^{* * *}$ & $0.0001^{* * *}$ & $0.0001^{* * *}$ \\
\hline & $(0.00000)$ & $(0.00000)$ & $(0.00000)$ & $(0.00000)$ & $(0.00000)$ & $(0.00000)$ \\
\hline Year dummies & YES & YES & YES & YES & YES & YES \\
\hline $\begin{array}{l}\text { Industry } \\
\text { dummies }\end{array}$ & YES & YES & YES & YES & YES & YES \\
\hline $\mathrm{N}$ & 1258 & 1258 & 1887 & 1887 & 3145 & 3145 \\
\hline Adj. R-square & 0.4556 & 0.329 & 0.416 & 0.3379 & 0.3972 & 0.3377 \\
\hline
\end{tabular}

All regressions used an adjusted-standard error for heteroscedasticity, and the values are reported in parentheses. ${ }^{* * *},{ }^{* *}$, and ${ }^{*}$ denote statistical significance at the $1 \%, 5 \%$, and $10 \%$ levels, respectively.

Model (1) of Panel A in Table 5 presents the results for samples with KZ index values in the lowest $20 \%$. The coefficient of $G H$ was -0.00979 , and it was not statistically significant. However, the coefficient was -0.00231 and statistically significant at the $1 \%$ level in Model (2). The results using samples with $\mathrm{KZ}$ index values in the top and bottom $30 \%$ were similar to the results in Models (3) and (4). Comparing the samples with $\mathrm{KZ}$ index values in the top $50 \%$ to the samples with values in the bottom $50 \%$ revealed that the coefficients of $G H$ on dividend yield were all statistically significant but were more negative for the more financially constrained firms (i.e., Column 6 of Panel A in Table 5).

In Panel B of Table 5, the regression used HFV as a proxy for information asymmetry. Overall, the results were similar to those for the models that used GH. The negative relationships between information asymmetry and corporate dividend yields are strong for the firms that have a high $\mathrm{KZ}$ index value. Therefore, the higher the information asymmetry, the greater the tendency for financially constrained firms to reduce their dividend yield on average. In sum, the results of Table 5 support Hypothesis 2.

Table 6 reports the regression results on the effects of information asymmetry on corporate dividend payouts across firms' costs of equity financing, estimated by stock liquidity. Firms with high stock liquidity find it easy to raise capital [41] and require a lower 
return from investors than firms with low liquidity [42]. Therefore, liquidity stocks reduce the cost of equity financing [43]. This study used the turnover ratio of stocks as a proxy for stock liquidity and classified the samples according to the top and bottom $20 \%, 30 \%$, and $50 \%$, respectively, based on the turnover ratio of stocks. Hypothesis 2 suggests that firms with low stock liquidity are likely to prefer internal capital because they find it more difficult to raise equity financing than firms with high liquidity. Following the pecking order theory, the negative relationship between information asymmetry and dividend payouts is particularly strong when firms with low stock liquidity also feature information asymmetry.

Model (1) of Panel A in Table 6 presents the result for samples with a turnover ratio of stocks (i.e., VolumnTurnOver) in the lowest 20\%. The coefficient of GH was -0.00101 and statistically significant at the $1 \%$ level. However, the coefficient was 0.01197 , and it was not statistically significant in Model (2). The results were similar in the subsample analyses using the top and bottom $30 \%$ and $50 \%$. The results using HFV in Panel B of Table 6 were also similar. The negative relationships between information asymmetry and dividend yields were strong when the firms belonged to the low-liquidity groups. Therefore, the results in Table 6 support Hypothesis 2.

Table 6. Effects of firm's information asymmetry on dividend policy by stock liquidity.

\begin{tabular}{|c|c|c|c|c|c|c|}
\hline \multicolumn{7}{|c|}{ [Panel A: Result Using GH] } \\
\hline & $\begin{array}{c}\text { Low } 20 \% \\
\text { (1) }\end{array}$ & $\begin{array}{l}\text { High } 20 \% \\
\text { (2) }\end{array}$ & $\begin{array}{c}\text { Low } 30 \% \\
\text { (3) }\end{array}$ & $\begin{array}{l}\text { High } 30 \% \\
\text { (4) }\end{array}$ & $\begin{array}{l}\text { Low } 50 \% \\
\text { (5) }\end{array}$ & $\begin{array}{l}\text { High } 50 \% \\
\text { (6) }\end{array}$ \\
\hline GH & $\begin{array}{c}-0.00101 * * * \\
(0.00034)\end{array}$ & $\begin{array}{c}0.01197 \\
(0.01607)\end{array}$ & $\begin{array}{c}-0.00119 * * * \\
(0.00032)\end{array}$ & $\begin{array}{c}0.00244 \\
(0.01337)\end{array}$ & $\begin{array}{c}-0.00152^{* * *} \\
(0.00034)\end{array}$ & $\begin{array}{c}-0.01095^{*} \\
(0.0059)\end{array}$ \\
\hline EquityBeta & $\begin{array}{c}-0.00888^{* * *} \\
(0.00195)\end{array}$ & $\begin{array}{c}-0.00125 \\
(0.0009)\end{array}$ & $\begin{array}{c}-0.00755^{* * *} \\
(0.00156)\end{array}$ & $\begin{array}{c}-0.00272^{* * *} \\
(0.00085)\end{array}$ & $\begin{array}{c}-0.00756^{* * *} \\
(0.00113)\end{array}$ & $\begin{array}{c}-0.00476^{* * *} \\
(0.00079)\end{array}$ \\
\hline KZIndex & $\begin{array}{c}-0.00005^{* * *} \\
(0.00002)\end{array}$ & $\begin{array}{c}-0.00004^{* * *} \\
(0.00002)\end{array}$ & $\begin{array}{c}-0.00005^{* * *} \\
(0.00001)\end{array}$ & $\begin{array}{c}-0.00008^{* * *} \\
(0.00002)\end{array}$ & $\begin{array}{c}-0.00004^{* * *} \\
(0.00001)\end{array}$ & $\begin{array}{l}-0.00001 \\
(0.00001)\end{array}$ \\
\hline $\begin{array}{l}\text { VolumeTurn } \\
\text { Over }\end{array}$ & $\begin{array}{c}0.27694^{* * *} \\
(0.06355)\end{array}$ & $\begin{array}{c}-0.00043^{* * *} \\
(0.00013)\end{array}$ & $\begin{array}{c}0.13562 * * * \\
(0.03796)\end{array}$ & $\begin{array}{c}-0.0005^{* * *} \\
(0.00015)\end{array}$ & $\begin{array}{c}0.03912^{* * * *} \\
(0.01398)\end{array}$ & $\begin{array}{c}-0.00077^{* * *} \\
(0.00015)\end{array}$ \\
\hline Size & $\begin{array}{c}-0.00207^{* * *} \\
(0.00055)\end{array}$ & $\begin{array}{c}-0.00068 \text { * } \\
(0.00038)\end{array}$ & $\begin{array}{c}-0.00194^{* * *} \\
(0.00041)\end{array}$ & $\begin{array}{c}-0.00053 \text { * } \\
(0.00029)\end{array}$ & $\begin{array}{c}-0.00147^{* * *} \\
(0.00028)\end{array}$ & $\begin{array}{c}-0.00052 \text { ** } \\
(0.00021)\end{array}$ \\
\hline DebtRatio & $\begin{array}{c}-0.00759 * * \\
(0.00329)\end{array}$ & $\begin{array}{c}-0.00952^{* * *} \\
(0.00225)\end{array}$ & $\begin{array}{c}-0.00816^{* * *} \\
(0.0029)\end{array}$ & $\begin{array}{c}-0.00805^{* * *} \\
(0.00204)\end{array}$ & $\begin{array}{c}-0.00877^{* * *} \\
(0.00214)\end{array}$ & $\begin{array}{c}-0.01054^{* * *} \\
(0.00175)\end{array}$ \\
\hline Collateral & $\begin{array}{c}0.00335 \\
(0.00317)\end{array}$ & $\begin{array}{c}-0.00294 \\
(0.00232)\end{array}$ & $\begin{array}{c}0.00100 \\
(0.00271)\end{array}$ & $\begin{array}{l}-0.00100 \\
(0.00214)\end{array}$ & $\begin{array}{l}-0.00062 \\
(0.00211)\end{array}$ & $\begin{array}{c}-0.00393 \text { ** } \\
(0.00191)\end{array}$ \\
\hline BookToMarket & $\begin{array}{c}0.00219^{* * *} \\
(0.00064)\end{array}$ & $\begin{array}{c}0.00115^{* * * *} \\
(0.00037)\end{array}$ & $\begin{array}{c}0.00211^{* * *} \\
(0.00055)\end{array}$ & $\begin{array}{c}0.00156^{* * * *} \\
(0.00035)\end{array}$ & $\begin{array}{c}0.00148^{* * * *} \\
(0.00042)\end{array}$ & $\begin{array}{c}0.00165^{* * * *} \\
(0.00033)\end{array}$ \\
\hline Profitability & $\begin{array}{c}0.04889^{* * *} \\
(0.00871)\end{array}$ & $\begin{array}{c}0.02006^{* * * *} \\
(0.00318)\end{array}$ & $\begin{array}{c}0.04926^{* * *} \\
(0.00715)\end{array}$ & $\begin{array}{c}0.02596^{* * * *} \\
(0.00307)\end{array}$ & $\begin{array}{l}0.0499^{* * *} \\
(0.00534)\end{array}$ & $\begin{array}{c}0.03006^{* * * *} \\
(0.00303)\end{array}$ \\
\hline FreeCashFlow & $\begin{array}{c}0.02383 * * * \\
(0.00758)\end{array}$ & $\begin{array}{c}0.02260 * * * \\
(0.00408)\end{array}$ & $\begin{array}{c}0.03108^{* * *} \\
(0.00626)\end{array}$ & $\begin{array}{c}0.02314^{* * *} \\
(0.00371)\end{array}$ & $\begin{array}{c}0.02772^{* * *} \\
(0.00485)\end{array}$ & $\begin{array}{c}0.02670 * * * \\
(0.0034)\end{array}$ \\
\hline SalesGrowth & $\begin{array}{c}0.00033 \\
(0.00104)\end{array}$ & $\begin{array}{c}0.00057 \\
(0.00085)\end{array}$ & $\begin{array}{l}-0.00039 \\
(0.00101)\end{array}$ & $\begin{array}{l}-0.00019 \\
(0.00073)\end{array}$ & $\begin{array}{l}-0.00113 \\
(0.00078)\end{array}$ & $\begin{array}{c}0.00036 \\
(0.00059)\end{array}$ \\
\hline IncomeGrowth & $\begin{array}{c}0.00000 \\
(0.00000)\end{array}$ & $\begin{array}{c}0.00050 * * * \\
(0.00000)\end{array}$ & $\begin{array}{c}0.00020 \\
(0.00000)\end{array}$ & $\begin{array}{c}0.00040^{* * * *} \\
(0.00000)\end{array}$ & $\begin{array}{l}0.00030 * * \\
(0.00000)\end{array}$ & $\begin{array}{c}0.00030^{* * * *} \\
(0.00000)\end{array}$ \\
\hline Ownership & $\begin{array}{c}0.00020^{* * *} \\
(0.00000)\end{array}$ & $\begin{array}{c}0.00010 * * * \\
(0.00000)\end{array}$ & $\begin{array}{c}0.00020 * * * \\
(0.00000)\end{array}$ & $\begin{array}{c}0.00010^{* * * *} \\
(0.00000)\end{array}$ & $\begin{array}{l}0.0002 * * * \\
(0.00000)\end{array}$ & $\begin{array}{c}0.00010^{* * * *} \\
(0.00000)\end{array}$ \\
\hline Year dummies & YES & YES & YES & YES & YES & YES \\
\hline $\begin{array}{l}\text { Industry } \\
\text { dummies }\end{array}$ & YES & YES & YES & YES & YES & YES \\
\hline $\mathrm{N}$ & 1258 & 1258 & 1887 & 1887 & 3145 & 3145 \\
\hline
\end{tabular}


Table 6. Cont.

\begin{tabular}{|c|c|c|c|c|c|c|}
\hline \multicolumn{7}{|c|}{ [Panel B: Result Using HFV] } \\
\hline & Low 20\% & High $20 \%$ & Low $30 \%$ & High $30 \%$ & Low 50\% & High $50 \%$ \\
\hline & (1) & (2) & (3) & (4) & (5) & (6) \\
\hline & $-0.00106^{* * *}$ & 0.01082 & $-0.00123^{* * *}$ & 0.00266 & $-0.00155^{* * *}$ & $-0.01071 *$ \\
\hline$H F V$ & $(0.00032)$ & $(0.01584)$ & $(0.00031)$ & $(0.01329)$ & $(0.00033)$ & $(0.00567)$ \\
\hline \multirow{2}{*}{ EquityBeta } & $-0.00883^{* * *}$ & -0.00125 & $-0.00751^{* * *}$ & $-0.00272^{* * *}$ & $-0.00755^{* * *}$ & $-0.00476^{* * *}$ \\
\hline & $(0.00195)$ & $(0.00091)$ & $(0.00156)$ & $(0.00085)$ & $(0.00113)$ & $(0.00079)$ \\
\hline \multirow{2}{*}{ KZIndex } & $-0.00005^{* * *}$ & $-0.00004^{* * *}$ & $-0.00005^{* * *}$ & $-0.00008^{* * *}$ & $-0.00004^{* * *}$ & -0.00001 \\
\hline & $(0.00002)$ & $(0.00002)$ & $(0.00001)$ & $(0.00002)$ & $(0.00001)$ & $(0.00001)$ \\
\hline VolumeTurn & $0.27625^{* * *}$ & $-0.00043^{* * *}$ & $0.13494^{* * *}$ & $-0.00050^{* * *}$ & $0.03881^{* * *}$ & $-0.00077^{* * *}$ \\
\hline Over & $(0.06352)$ & $(0.00013)$ & $(0.03798)$ & $(0.00015)$ & $(0.01398)$ & $(0.00015)$ \\
\hline \multirow{2}{*}{ Size } & $-0.00205^{* * *}$ & $-0.00067^{*}$ & $-0.00193^{* * *}$ & $-0.00053^{*}$ & $-0.00147^{* * *}$ & $-0.00052^{* *}$ \\
\hline & (0.00055) & $(0.00038)$ & $(0.00041)$ & $(0.00029)$ & $(0.00028)$ & $(0.00021)$ \\
\hline \multirow{2}{*}{ DebtRatio } & $-0.00765^{* *}$ & $-0.00953^{* * *}$ & $-0.0082^{* * *}$ & $-0.00805^{* * *}$ & $-0.00881^{* * *}$ & $-0.01054^{* * *}$ \\
\hline & $(0.0033)$ & $(0.00225)$ & (0.0029) & $(0.00204)$ & $(0.00214)$ & $(0.00175)$ \\
\hline \multirow{2}{*}{ Collateral } & 0.00338 & -0.00294 & 0.00102 & -0.00100 & -0.00061 & $-0.00393^{* *}$ \\
\hline & $(0.00317)$ & $(0.00232)$ & $(0.00271)$ & $(0.00214)$ & $(0.00211)$ & $(0.00191)$ \\
\hline \multirow{2}{*}{ BookToMarket } & $0.00219^{* * *}$ & $0.00115^{* * *}$ & $0.00211^{* *}$ & $0.00156^{* * *}$ & $0.00148^{* * *}$ & $0.00165^{* * *}$ \\
\hline & $(0.00064)$ & $(0.00037)$ & $*(0.00055)$ & $(0.00035)$ & $(0.00042)$ & $(0.00033)$ \\
\hline \multirow{2}{*}{ Profitability } & $0.04892^{* * *}$ & $0.02006^{* * *}$ & $0.04929 * * *$ & $0.02596^{* * * *}$ & $0.04992 * * *$ & $0.03007^{* * * *}$ \\
\hline & $(0.0087)$ & $(0.00318)$ & $(0.00714)$ & $(0.00307)$ & $(0.00534)$ & $(0.00304)$ \\
\hline \multirow{2}{*}{ FreeCashFlow } & $0.02379 * * *$ & $0.02259 * * *$ & $0.03103^{* * *}$ & $0.02314^{* * *}$ & $0.02768 * * *$ & $0.02670 * * *$ \\
\hline & $(0.00758)$ & $(0.00408)$ & $(0.00626)$ & $(0.00371)$ & $(0.00485)$ & $(0.0034)$ \\
\hline \multirow{2}{*}{ SalesGrowth } & 0.00032 & 0.00057 & -0.00039 & -0.00019 & -0.00114 & 0.00036 \\
\hline & $(0.00104)$ & $(0.00085)$ & $(0.00101)$ & $(0.00073)$ & $(0.00078)$ & $(0.00059)$ \\
\hline \multirow{2}{*}{ IncomeGrowth } & 0.00000 & $0.00050 * * *$ & 0.00020 & $0.0004^{* * *}$ & $0.00030 * *$ & $0.00030 * * *$ \\
\hline & $(0.00000)$ & $(0.00000)$ & $(0.00000)$ & $(0.00000)$ & $(0.00000)$ & $(0.00000)$ \\
\hline \multirow{2}{*}{ Ownership } & $0.00020^{* * *}$ & $0.00010^{* * *}$ & $0.00020 * * *$ & $0.00010^{* * *}$ & $0.00020 * * *$ & $0.00010^{* * *}$ \\
\hline & $(0.00000)$ & $(0.00000)$ & $(0.00000)$ & $(0.00000)$ & $(0.00000)$ & $(0.00000)$ \\
\hline Year dummies & YES & YES & YES & YES & YES & YES \\
\hline $\begin{array}{l}\text { Industry } \\
\text { dummies }\end{array}$ & YES & YES & YES & YES & YES & YES \\
\hline $\mathrm{N}$ & 1258 & 1258 & 1887 & 1887 & 3145 & 3145 \\
\hline Adj. R-square & 0.3276 & 0.2689 & 0.336 & 0.3066 & 0.3556 & 0.3058 \\
\hline
\end{tabular}

All regressions used an adjusted-standard error for heteroscedasticity, and the values are reported in parentheses. ${ }^{* * *},{ }^{* *}$ and ${ }^{*}$ denote statistical significance at the $1 \%, 5 \%$, and $10 \%$ levels, respectively.

\subsection{Robustness}

We found a negative relationship between information asymmetry and dividend payout. We also found that the negative relationship is particularly strong for firms facing a high cost of raising capital or restricted ability to raise external financing. This study was controlled for many observable and financial characteristics, but firms with dividend payouts may have unobservable characteristics that differ from those of firms without dividend payouts. In Korea's public market, the top 200 listed firms account for 70\% of corporate market capitalization, implying a wide disparity in firm size. Most firms operate businesses of negligible size or are under severe capital constraints, and a number of them have no disposable funds for dividend payouts. Dividend yields for stocks comprising the KRX indices in 2013 showed that dividend yields for most of the firms were between $0.5 \%$ and $2 \%$, suggesting that Korean firms are generally reluctant to pay dividends. Thus, comparing financial and accounting variables between firms that frequently pay dividends and those that do not may exclude some difficult-to-observe characteristics.

To address this endogeneity issue, this study examined the difference between dividendpaying and non-dividend-paying firms. In our sample, however, only 183 firms (14.8\% of the sample) had never paid cash dividends during the sample period. Such a small sample size may not produce reliable results. Therefore, this study used samples with fewer 
than four dividend payments as a control group. We used the firms with more than four dividend payments as a treatment group and matched it with the non-dividend-paying sample using propensity score matching. When calculating Mahalanobis distances, we used all the control variables (the variables indicate financing condition (beta, KZ index, turnover ratio of stocks), firm size, debt ratio, collateral ability, firm value (book-to-market ratio), operating free cash flow, sales growth, and income growth) of our empirical model because these variables affect corporate dividend policy. We also added the condition that the caliper width for propensity score matching is 0.2, following Austin [45].

Table 7 reports the results of the robustness check. In Models (1) and (2) of Table 7, we used only the matched samples, and the models contained GH and $H F V$, respectively. The number of matched samples was 2778, with 1389 each for the treatment and control groups. We found that the coefficients of the information asymmetry variable (InforAsym) on dividend yields were both negative and statistically significant at the $5 \%$ level.

Table 7. Robustness checks.

\begin{tabular}{|c|c|c|c|c|c|c|c|c|}
\hline & \multicolumn{2}{|c|}{ Matched Four Times } & \multicolumn{2}{|c|}{ Matched Eight Times } & \multicolumn{2}{|c|}{ Dividend-Paying Sample } & \multicolumn{2}{|c|}{ Average InforAsym } \\
\hline & $\begin{array}{l}G H \\
\text { (1) }\end{array}$ & $\begin{array}{c}H F V \\
(2)\end{array}$ & $\begin{array}{l}G H \\
\text { (3) }\end{array}$ & $\underset{(4)}{H F V}$ & $\begin{array}{l}G H \\
(5)\end{array}$ & $\begin{array}{c}H F V \\
(6)\end{array}$ & $\begin{array}{c}G H 3 \\
(7)\end{array}$ & $\underset{(8)}{H F V 3}$ \\
\hline Infor & $-0.00236^{* *}$ & $-0.00254 * *$ & $-0.00159 * *$ & $-0.0016^{* *}$ & $-0.0018^{* * *}$ & $-0.00183^{* * *}$ & $-0.00496 * * *$ & $-0.00488^{* * *}$ \\
\hline Asym & $(0.00099)$ & $(0.00101)$ & $(0.00068)$ & $(0.00065)$ & $(0.00038)$ & $(0.00036)$ & $(0.00061)$ & $(0.00057)$ \\
\hline Equity & $-0.00338^{* * *}$ & $-0.00338^{* * *}$ & $-0.00314^{* * *}$ & $-0.00314^{* * *}$ & $-0.00605^{* * *}$ & $-0.00605^{* * *}$ & $-0.00618^{* * *}$ & $-0.0062 * * *$ \\
\hline Beta & $(0.00083)$ & $(0.00083)$ & $(0.0008)$ & $(0.0008)$ & $(0.00066)$ & $(0.00066)$ & $(0.0006)$ & $(0.0006)$ \\
\hline & $-0.00005^{* * *}$ & $-0.00005^{* * *}$ & $-0.00009^{* * *}$ & $-0.00009^{* * *}$ & -0.00001 & -0.00001 & -0.00001 & -0.00001 \\
\hline KZlndex & $(0.00002)$ & $(0.00002)$ & $(0.00002)$ & $(0.00002)$ & $(0.00001)$ & $(0.00001)$ & $(0.00001)$ & $(0.00001)$ \\
\hline Volume & $-0.00116^{* * *}$ & $-0.00116^{* * *}$ & $-0.00131^{* * *}$ & $-0.00131^{* * *}$ & $-0.0012^{* * *}$ & $-0.0012^{* * *}$ & $-0.00098^{* * *}$ & $-0.00098^{* * *}$ \\
\hline TurnOver & $(0.00027)$ & (0.00027) & $(0.0003)$ & $(0.0003)$ & $(0.0002)$ & $(0.0002)$ & $(0.00015)$ & $(0.00015)$ \\
\hline Size & $\begin{array}{c}-0.00047^{*} \\
(0.00025)\end{array}$ & $\begin{array}{c}-0.00047^{*} \\
(0.00025)\end{array}$ & $\begin{array}{c}-0.00072 * * * \\
(0.00023)\end{array}$ & $\begin{array}{c}-0.00072^{* * *} \\
(0.00023)\end{array}$ & $\begin{array}{c}-0.00158^{* * *} \\
(0.00019)\end{array}$ & $\begin{array}{c}-0.00158^{* * *} \\
(0.00019)\end{array}$ & $\begin{array}{c}-0.00078^{* * *} \\
(0.00017)\end{array}$ & $\begin{array}{c}-0.00077^{* * *} \\
(0.00017)\end{array}$ \\
\hline DebtRatio & $\begin{array}{c}-0.00869^{* * *} \\
(0.0019)\end{array}$ & $\begin{array}{c}-0.00871 \\
(0.0019)\end{array}$ & $\begin{array}{c}-0.00658 * * * \\
(0.0019)\end{array}$ & $\begin{array}{c}-0.00661 \\
(0.0019)\end{array}$ & $\begin{array}{c}-0.00765 * * * \\
(0.00158)\end{array}$ & $\begin{array}{c}-0.00768 * * * \\
(0.00158)\end{array}$ & $\begin{array}{c}-0.01131 \\
(0.00137)\end{array}$ & $\begin{array}{c}-0.01134^{* * * *} \\
(0.00137)\end{array}$ \\
\hline & -0.00195 & -0.00193 & -0.00232 & -0.0023 & -0.00115 & -0.00114 & -0.00191 & -0.0019 \\
\hline Collateral & $(0.00198)$ & $(0.00198)$ & $(0.00192)$ & (0.00192) & $(0.00158)$ & $(0.00158)$ & $(0.0014)$ & $(0.0014)$ \\
\hline BookTo & $0.00207^{* * *}$ & $0.00207^{* * *}$ & $0.00237^{* * *}$ & $0.00237^{* * *}$ & $0.00146^{* * *}$ & $0.00146^{* * *}$ & $0.00157^{* * *}$ & $0.00157^{* * *}$ \\
\hline Market & $(0.00034)$ & $(0.00034)$ & $(0.00034)$ & $(0.00034)$ & (0.0003) & (0.0003) & $(0.00025)$ & $(0.00025)$ \\
\hline Profitability & $\begin{array}{c}0.04746^{* * * *} \\
(0.00457)\end{array}$ & $\begin{array}{c}0.04745^{* * *} \\
(0.00457)\end{array}$ & $\begin{array}{c}0.05482 * * * \\
(0.00525)\end{array}$ & $\begin{array}{c}0.05477^{* * *} \\
(0.00525)\end{array}$ & $\begin{array}{c}0.05018^{* * *} \\
(0.00368)\end{array}$ & $\begin{array}{c}0.05018 * * * \\
(0.00368)\end{array}$ & $\begin{array}{c}0.03669 * * * \\
(0.00265)\end{array}$ & $\begin{array}{c}0.03668 * * * \\
(0.00265)\end{array}$ \\
\hline FreeCash & $0.01644^{* * *}$ & $0.01644^{* * *}$ & $0.02204^{* * *}$ & $0.02206^{* * *}$ & $0.02421^{* * *}$ & $0.02418^{* * *}$ & $0.02805^{* * *}$ & $0.02804^{* * *}$ \\
\hline Flow & $(0.00391)$ & $(0.00391)$ & $(0.00385)$ & $(0.00385)$ & $(0.0033)$ & $(0.0033)$ & $(0.00279)$ & $(0.00279)$ \\
\hline Sales & 0.00041 & 0.00041 & 0.00052 & 0.00052 & -0.00033 & -0.00033 & -0.00032 & -0.00032 \\
\hline Growth & $(0.00074)$ & $(0.00074)$ & $(0.00074)$ & $(0.00074)$ & $(0.00061)$ & $(0.00061)$ & $(0.00048)$ & $(0.00048)$ \\
\hline Income & $0.0002 * * *$ & $0.0002 * * *$ & 0.0001 * & 0.0001 * & $0.0002 * * *$ & $0.0002 * * *$ & $0.0003^{* * *}$ & $0.0003^{* * *}$ \\
\hline Growth & $(0.00000)$ & $(0.00000)$ & $(0.00000)$ & $(0.00000)$ & $(0.00000)$ & $(0.00000)$ & $(0.00000)$ & $(0.00000)$ \\
\hline Ownership & $\begin{array}{l}0.0001^{* * *} \\
(0.00000)\end{array}$ & $\begin{array}{l}0.0001 * * * \\
(0.00000)\end{array}$ & $\begin{array}{l}0.0001^{* * *} \\
(0.00000)\end{array}$ & $\begin{array}{l}0.0001^{* * *} \\
(0.00000)\end{array}$ & $\begin{array}{l}0.0002 * * * \\
(0.00000)\end{array}$ & $\begin{array}{l}0.0002 * * * \\
(0.00000)\end{array}$ & $\begin{array}{l}0.0001 * * * \\
(0.00000)\end{array}$ & $\begin{array}{l}0.0001^{* * *} \\
(0.00000)\end{array}$ \\
\hline $\begin{array}{c}\text { Year } \\
\text { dummies }\end{array}$ & YES & YES & YES & YES & YES & YES & YES & YES \\
\hline $\begin{array}{l}\text { Industry } \\
\text { dummies }\end{array}$ & YES & YES & YES & YES & YES & YES & YES & YES \\
\hline N & 2778 & 2778 & 3174 & 3174 & 5491 & 5491 & 6290 & 6290 \\
\hline $\begin{array}{c}\text { Adj. } \\
\text { R-square }\end{array}$ & 0.2472 & 0.2473 & 0.2708 & 0.2708 & 0.3445 & 0.3446 & 0.3491 & 0.3492 \\
\hline
\end{tabular}

All regressions used an adjusted-standard error for heteroscedasticity, and the values are reported in parentheses. ${ }^{* * *},{ }^{* *}$, and ${ }^{*}$ denote statistical significance at the $1 \%, 5 \%$, and $10 \%$ levels, respectively.

However, the criterion of paying dividends more than four times within 9 years may be ambiguous. The mean and median of the number of dividends paid by the sample firms was 7.3 and 8, respectively. Therefore, we further analyzed the matched sample consisting of firms that have paid dividends more than eight times in the sample period. The results of the analysis of the samples rematched using this criterion are reported in Models (3) and (4) in Table 7. The number of matched samples was 3174, with 1587 each for the treatment and control groups. We found that the coefficients of the information asymmetry variable (InforAsym) on dividend yields were both negative and statistically significant at the $5 \%$ level.

Models (5) and (6) of Table 7 present subsample regressions using only dividendpaying firms. During the sample period (9 years), 183 of the sample firms never paid cash dividends. Our results were consistent when those firms were excluded. The coefficients 
of the information asymmetry variables were both negative and statistically significant at the $1 \%$ level.

In terms of dividend policies, investors and managers consider information asymmetry not only for the given year but also for past years. Therefore, this study calculated the average values of GH and HFV for the 3 years before the given year. Models (7) and (8) show the effects of average levels of information asymmetry. The coefficients of the information asymmetry variables were both negative and statistically significant at the $1 \%$ level.

Thus, the results of considering average levels of information asymmetry for several subsamples were similar to our main results.

Our findings show a negative relationship between levels of information asymmetry and dividend payout when direct information asymmetry variables are used. This negative relationship is more pronounced for risky firms and firms with financial constraints or low stock liquidity. These results support the pecking order theory that companies tend to secure internal funding by reducing dividends when it costs more to obtain external funding.

\section{Conclusions}

This study analyzed the effects of corporate information asymmetry on dividend payouts using HFV and $G H$, which allowed us to measure information asymmetry directly and without using other accounting variables. We found that the corporate dividend yield decreases with the degree of information asymmetry in Korean public firms. These results suggest that firms with high information asymmetry tend to prefer internal capital, supporting the pecking order theory, and that there is, therefore, a negative relation between information asymmetry and dividend yields on average.

The signaling view of dividends predicts a positive relationship between information asymmetry and dividend yields. According to the signaling view, companies with high information asymmetry may relieve the uncertainty experienced by outside investors by returning corporate performance to shareholders. However, problems arise when dividend payouts fail to deliver information to investors as managers expected. In this situation, companies whose internal capital has been reduced due to dividend payouts have to bear high external capital costs due to information asymmetry. While it is important for the companies to provide adequate returns to shareholders for corporate sustainability, it is also important for financial managers to establish a reasonable capital budget and a capital financing plan to implement it.

This study has found that the negative relationship between information asymmetry and dividend yields is related primarily to the cost of raising capital. We used three measures as a proxy for this cost: the beta coefficient (firm risk), the KZ index (financial constraints), and the turnover ratio of stocks (liquidity of stocks). Firms that find it difficult to raise capital (or have a high cost of capital) and also feature a high degree of information asymmetry find it more difficult to raise external capital. Therefore, they are reluctant to make dividend payouts and prefer to hold internal capital. As a result, their dividend yields are lower than are those of other firms. Our results support the view that the negative impact of information asymmetry on dividend payouts is stronger for firms that struggle to raise external capital than it is for firms that do not.

This study is the first to show that information asymmetry has an important influence on dividend decisions using a direct variable based on market microstructure. This study is expected to make an important contribution to policy decisions driven by the ability to identify the companies most likely to increase their dividends.

Author Contributions: Conceptualization, S.K. and J.-y.J.; methodology, S.K.; validation, S.K. and J.-y.J.; formal analysis, S.K.; investigation, J-y.J.; resources, S.-w.C.; data curation, S.K.; writing —original draft preparation, S.K.; writing - review and editing, J.-y.J. and S.-w.C.; supervision, J.-y.J., S.-w.C., and S.K. All authors have read and agreed to the published version of the manuscript.

Funding: This research received no external funding. 
Conflicts of Interest: The authors declare no conflict of interest.

\section{References}

1. Miller, M.; Rock, K. Dividend policy under asymmetric information. J. Financ. 1985, 40, 1031-1051. [CrossRef]

2. Bhattacharya, S. Imperfect information, dividend policy, and "the bird in the hand" fallacy. Bell J. Econ. 1979, 10, 259-270. [CrossRef]

3. Allen, F.; Bernardo, A.E.; Welch, L. A theory of dividends based on tax clienteles. J. Financ. 2000, 55, 2499-2536. [CrossRef]

4. Charest, G. Dividend information, stock returns and market efficiency-II. J. Financ. Econ. 1978, 2-3, 297-330. [CrossRef]

5. Dielman, T.E.; Oppenheimer, H.R. An examination of investor behavior during periods of large dividend changes. J. Financ. Quant. Anal. 1984, 19, 197-216. [CrossRef]

6. Carroll, C.R.; Sears, R.S. Dividend announcements and changes in beta. Financ. Rev. 1994, 29, 371-393. [CrossRef]

7. Myers, S.C.; Majluf, N. Corporate financing and investment decisions when firms have information that investors do not have. J. Financ. Econ. 1984, 13, 187-221. [CrossRef]

8. Deshmukh, S. The effect of asymmetry information on dividend policy. Q. J. Bus. Econ. 2005, 44, 107-127.

9. Kim, T.; Kim, I. The effect of information asymmetry on dividend payment: From the perspective of pecking order and signaling. Korean J. Financ. Manag. 2017, 34, 63-84.

10. Atiase, R.K. Pre-disclosure information, firm capitalization, and security price behavior around earnings announcements. $J$ Account. Res. 1985, 23, 21-35. [CrossRef]

11. Bhushan, R. Firm characteristics and analyst following. J. Account. Econ. 1989, 11, 255-274. [CrossRef]

12. Shores, D. The association between interim information and security returns surrounding earnings announcement. J. Account. Res. 1990, 26, 164-181. [CrossRef]

13. Dewenter, K.L.; Warther, V.A. Dividends, asymmetric information, and agency conflicts: Evidence from a comparison of the dividend policies of Japanese and U.S. firms. J. Financ. 1998, 53, 879-904. [CrossRef]

14. Michaely, R.; Robert, M.R. Corporate dividend policies: Lessons from private firms. Rev. Financ. Stud. 2012, 25, 711-746. [CrossRef]

15. Li, K.; Zhao, X. Asymmetric information and dividend policy. Financ. Manag. 2008, 37, 673-694. [CrossRef]

16. Deangelo, H.; Deangelo, L. Dividend policy and financial distress: An empirical investigation of troubled NYSE firms. J. Financ. 1990, 45, 1415-1431. [CrossRef]

17. Grullon, G.; Michaely, R. Dividends, share repurchases, and substitution hypothesis. J. Financ. 2002, 57, 1649-1684. [CrossRef]

18. Baker, H.K.; Farrelly, G.E.; Edelman, R.B. A survey of management views on dividend policy. Financ. Manag. 1985, 14, 78-84. [CrossRef]

19. Michaely, R.; Thaler, R.; Womack, K. Price reactions to dividend initiations and omissions: Overreaction or drift? J. Financ. 1995, 50, 573-608. [CrossRef]

20. Lang, L.H.P.; Litzenberger, R.H. Dividend announcements: Cash flow signalling vs. free cash flow hypothesis? J. Financ. Econ. 1989, 24, 181-191. [CrossRef]

21. La Porta, R.; Lopez-de-Silans, F.; Shleifer, F.; Vishny, R.W. Agency problems and dividend policies around the world. J. Financ. 2000, 55, 1-33. [CrossRef]

22. Easterbrook, F.H. Two agency cost explanations of dividends. Am. Econ. Rev. 1985, 74, 650-659.

23. Jensen, M. Agency costs of free cash-flow, corporate finance and takeovers. Am. Econ. Rev. 1986, 48, 831-880.

24. Agrawal, A.; Jayaraman, N. The dividend policies of all-equity firms: A direct test of the free cash flow theory. Manag. Decis. Econ. 1994, 15, 139-148. [CrossRef]

25. Deshmukh, S. Dividend initiations and asymmetric information: A hazard model. Financ. Rev. 2003, 38, 351-368. [CrossRef]

26. Kale, J.; Noe, T. Dividends, uncertainty, and underwriting costs under asymmetric information. J. Financ. Res. 1990, 13, 265-277. [CrossRef]

27. Collins, D.W.; Kothari, S.P.; Rayburn, J.D. Firm size and the information content of prices with respect to earnings. J. Account. Econ. 1987, 9, 111-138. [CrossRef]

28. Barth, M.E.; Kasznik, R.; McNichols, M.F. Analyst coverage and intangible assets. J. Account. Res. 2002, 39, 1-34. [CrossRef]

29. Glosten, L.R.; Harris, L.E. Estimating the components of the bid/ask spread. J. Financ. Econ. 1988, 21, 123-142. [CrossRef]

30. Hasbrouck, J. Measuring the information content of stock trades. J. Financ. 1991, 46, 179-207. [CrossRef]

31. Foster, F.D.; Viswanathan, S. Variation in trading volume, return volatility, and trading costs: Evidence on recent price formation models. J. Financ. 1993, 48, 187-211. [CrossRef]

32. Glosten, L.R.; Milgrom, P.R. Bid, ask, and transaction prices in a specialist market with heterogeneously informed traders. J. Financ. Econ. 1985, 14, 71-100. [CrossRef]

33. Brennan, M.J.; Subrahmanyam, A. Market microstructure and asset pricing: On the compensation for illiquidity in stock returns. J. Financ. Econ. 1996, 41, 441-464. [CrossRef]

34. Kyle, A.S. Continuous auctions and insider trading. Econometrica 1985, 53, 1315-1335. [CrossRef]

35. Sharpe, W.F. Capital asset prices: A theory of market equilibrium under conditions of risk. J. Financ. 1964, 19, 425-442.

36. Hamada, R.S. The effect of the firm's capital structure on the systematic risk of common stocks. J. Financ. 1972, $27,435-452$. [CrossRef] 
37. Bowman, R.G. The theoretical relationship between systematic risk and financial (accounting) variables. J. Financ. 1979, 34, 617-630. [CrossRef]

38. Brenner, M.; Smidt, S. Asset characteristics and systematic risk. Financ. Manag. 1978, 7, 33-39. [CrossRef]

39. Lamont, O.; Polk, C.; Saa-Requejo, J. Financial constraints and stock returns. Rev. Financ. Stud. 2001, 14, 529-554. [CrossRef]

40. Hadlock, C.J.; Pierce, J.R. New evidence on measuring financial constraints: Moving beyond the KZ index. Rev. Financ. Stud. 2010, 23, 1909-1940. [CrossRef]

41. Amihud, Y.; Hameed, A.; Kang, W.; Zhang, H. Stock liquidity and the cost of equity capital in global markets. J. Appl. Corp. Financ. 2015, 27, 68-74. [CrossRef]

42. Amihud, Y.; Mendelson, H. Asset pricing and the bid-ask spread. J. Financ. Econ. 1986, 17, 223-249. [CrossRef]

43. Butler, A.; Grullon, W.G.; Weston, J.P. Stock market liquidity and the cost of issuing equity. J. Financ. Quant. Anal. 2005, 40, 331-348. [CrossRef]

44. Faccio, M.; Masulis, R.W. The choice of payment method in European merger and acquisition. J. Financ. 2005, 60, 1345-1388. [CrossRef]

45. Austin, P.C. An introduction to propensity score methods for reducing the effects of confounding in observational. Multivar. Behav. Res. 2011, 46, 339-424. [CrossRef] 